\title{
O fracasso escolar de meninos e meninas: articulações entre gênero e cor/raça*
}

\author{
Marília Pinto de Carvalho**
}

\begin{abstract}
Resumo
Este artigo é parte de uma pesquisa que tem por objetivo conhecer os processos através dos quais se produz, no ensino fundamental, o fracasso escolar mais acentuado entre crianças negras do sexo masculino, conforme vêm indicando as estatísticas educacionais brasileiras há algumas décadas. A etapa aqui descrita investiga a categorização racial das crianças no âmbito escolar, apontando possíveis superposições entre os significados de masculinidade, pertencimento à raça negra e problemas escolares de disciplina e de desempenho, através de um estudo de natureza qualitativa, desenvolvido em uma escola de ensino fundamental ( $1^{\circ}$ Ciclo) utilizando questionários e entrevistas em profundidade. Nossa hipótese é que, pelo menos no âmbito da escola, a identidade racial de meninos e meninas seria construída tendo como referência não apenas características fenotípicas e status sócio-econômico, mas também seu desempenho escolar.
\end{abstract}

Palavras-chave: Desempenho Escolar, Ensino Fundamental, Gênero, Raça.

\footnotetext{
" Recebido para publicação em dezembro de 2003, aceito em abril de 2004. Esse texto foi originalmente apresentado no GT Educação e Sociedade, durante o $27^{\circ}$ encontro anual da ANPOCS. Agradeço a todos os participantes os comentários e sugestões, em especial à debatedora da seção, Maria Cristina Leal.

*** Professora da Faculdade de Educação da USP. mariliac@usp.br
} 
Articulações entre gênero e cor/raça

Boys' and Girls' Underachievement:

Articulating Gender and Race

\begin{abstract}
Educational statistics have shown that in Primary School underachievement seems to be more associated with black male children. This article is part of a research that intends to understand the processes that produce such situation. The present study investigates racial categorizations in the school showing possible juxtapositions among meanings of masculinity, race belonging (blackness), and bad behavior and underachievement through a qualitative study undertaken in a Primary School, with questionnaires and in depth interviews. Our hypotheses holds that, at least in the school context, boys' and girls' racial identities refer not only to phenotypic and social-economical features, but also to their schooling performance.
\end{abstract}

Key Words: School Underachievement, Primary School, Gender, Race. 
Marília Pinto de Carvalho

Há algumas décadas, as estatísticas nacionais vêm indicando uma nítida diferença de desempenho escolar entre meninos e meninas. ${ }^{1}$ Em relação ao tempo de estudo, por exemplo, os homens tinham em 1960 2,4 anos em média e as mulheres 1,9 , o que significa que o acesso à escola era em geral muito baixo e ainda pior para as mulheres. Ao longo dos últimos 40 anos, assistimos a uma forte ampliação do acesso à escola $e$ as médias nacionais hoje estão em torno de seis anos de escolaridade. Mas ao mesmo tempo, ocorreu uma inversão entre os grupos por sexo indicando que as mulheres foram as maiores beneficiadas, apresentando em 1999 5,9 anos de estudo em média, contra 5,6 para o sexo masculino. Essa diferença aparece de forma muito clara nos dados sobre níveis de analfabetismo, divididos por faixas etárias e sexo. Temos, entre os jovens, taxas de analfabetismo menores, devido ao maior acesso à escola em comparação a adultos e idosos. Mas considerando o recorte por sexo, nas faixas etárias acima de 45 anos vamos encontrar mais mulheres do que homens analfabetos, enquanto na faixa de 15 a 19 anos temos quase o dobro da proporção de rapazes (5,3\%) que moças analfabetas $(2,7 \%)$. Sabemos que a grande maioria desses jovens analfabetos passou pela escola e não conseguiu se apropriar da ferramenta da leitura e escrita, teve uma trajetória escolar marcada pela repetência e pela evasão e esse é um indicador de que a escola está fracassando frente a um grupo grande de jovens no qual se concentra uma maioria de pessoas do sexo masculino.

Essa diferença entre homens e mulheres se complexifica, entretanto, ao considerar-se ao mesmo tempo a variável "cor" ou "raça", apontando que os maiores problemas se referem ao grupo

1 Rosemberg, Fúlvia et alii. A educação da mulher no Brasil. São Paulo, Global, 1982; Educação formal e mulher: um balanço parcial In: CosTA, Albertina de O. \& BRUSCHINI, Cristina. (orgs.) Uma questão de gênero. Rio de Janeiro/São Paulo, Rosa dos Tempos/Fundação Carlos Chagas, 1992; Educação formal, mulher e gênero no Brasil contemporâneo. Estudos Feministas, vol. 9, n 2, Florianópolis, 2001. 
Articulações entre gênero e cor/raça

de alunos negros do sexo masculino. Apenas a título de exemplo, podemos observar, nos dados relativos à defasagem entre série cursada e idade, que pessoas negras de sexo masculino têm maiores dificuldades em sua trajetória escolar, seguidos de mulheres negras, homens brancos e, em melhor situação, mulheres brancas (Gráfico 1).

Sabemos que a evasão escolar, assim como trajetórias com muitas interrupções estão intimamente articuladas a sucessivas reprovações, todos eles problemas crônicos do sistema escolar brasileiro. Para interferir nessa situação, ao longo dos anos 90 foram implementadas diversas políticas de melhoria do fluxo escolar, que conduziram à aceleração de estudos, à organização do ensino em ciclos e à aprovação automática de alunos. Como resultado, dados nacionais mais recentes apontam grande diminuição nas taxas de repetência, que contudo não indicam necessariamente uma real melhoria no acesso ao conhecimento $e$ nem mesmo uma efetiva diminuição dos problemas escolares de disciplina e aprendizagem, antes diretamente refletidos no número de repetências.

Observadas a partir do funcionamento cotidiano das escolas, essas políticas, se por um lado parecem ter resultado numa maior inclusão escolar - o que é, sem dúvida, positivo - por outro lado, levaram a uma grande pressão sobre os professores para que aprovem o maior número possível de alunos nas séries em que ainda existe a reprovação (finais de ciclo). Essa situação, aliada à falta de condições efetivas para um trabalho de recuperação paralela da aprendizagem, para o bom funcionamento das classes de aceleração e mesmo para um trabalho pedagógico de qualidade nas classes regulares, leva-nos a duvidar dos efeitos dessas medidas sobre a efetiva apropriação do conhecimento por alunos e alunas, isto é, sobre a democratização do acesso ao saber.

Se por um lado essa apropriação do saber pode ser medida, pelo menos em parte, através da análise dos resultados de testes padronizados, tais como o SAEB (Sistema de Avaliação da 
Marília Pinto de Carvalho

Educação Básica) ${ }^{2}$, no âmbito do cotidiano escolar, alunos e alunas continuam sendo avaliados por seus professores $e$ professoras, através de conceitos como "suficiente" $e$ "insuficiente", indicações para aulas de reforço e mesmo reprovações ao final do ciclo. Embora decisivas no processo de construção das trajetórias escolares e até certo ponto indicadoras do sucesso ou não dos esforços pela democratização do conhecimento, essas avaliações constituem processos cotidianos, às vezes nem mesmo registrados em documentos minimamente formalizados, como pude constatar em investigação anterior. ${ }^{3}$

Tendo em vista esse quadro, o objetivo de conhecer as formas cotidianas de produção do fracasso escolar mais acentuado entre meninos negros impõe a necessidade de investigar as interações entre professores, professoras, alunos e alunas, sempre perpassadas por um conjunto de desigualdades sociais de raça, classe e gênero; assim como os critérios de avaliação adotados explícita ou implicitamente, mais ou menos conscientemente, pelos encarregados de avaliar $e$ atribuir conceitos ou notas aos alunos. Não se trata, nesse caso, de discutir se meninos ou meninas, negros ou brancos são mais aptos, mais rápidos ou mais afeitos à aprendizagem escolar em geral ou a alguma aprendizagem específica. Aqui, o foco estará sobre os processos que têm conduzido um maior número de meninos do que meninas - $e$, dentre eles, um maior número de meninos negros que brancos - a obter notas baixas ou conceitos negativos,

2 Diversos estudos vêm analisando esses resultados, por exemplo SOARES, J. F.; CÉSAR, C. C.; MAMBRINI, J. Determinantes de desempenho dos alunos do ensino básico brasileiro: evidências do SAEB de 1997. In: FRANCO, C. Promoção, ciclos e avaliação educacional. Porto Alegre, Artes Médicas, 2001, pp.121-153; SOARES, J. F; AlveS, M.T.G. Desigualdades raciais no sistema brasileiro de educação básica. Educação e Pesquisa, vol. 29, n 1, São Paulo, janeiro/junho de 2003, pp.147-165; e BonAmINO, A. M. C. Tempos de avaliação educacional: o SAEB, seus agentes, referências e tendências. Rio de Janeiro, Quartet, 2002.

3 Carvalho, Marilia Pinto de. Estatísticas de desempenho escolar: o lado avesso. Educação \& Sociedade, vol. 22, nº 77, dezembro de 2001, pp.231-252. 
Articulações entre gênero e cor/raça

e a ser indicados para atividades de recuperação. O que pode ou não - estar relacionado a sua efetiva aprendizagem $e$ a eventuais dificuldades frente ao conhecimento e ao mesmo tempo pode - ou não - ser refletido tanto nas taxas de evasão escolar e defasagem entre série $e$ idade, quanto nos resultados em testes padronizados.

Neste artigo, estarão em relevo as opiniões de professoras sobre as relações raciais e de gênero, assim como seus critérios de avaliação de alunos e alunas, com especial ênfase para a questão racial. ${ }^{4}$ Apesar de nos parecer um dos pontos de estrangulamento das atuais políticas educacionais, este aspecto é pouco discutido nas pesquisas da área e mesmo a literatura internacional parece tratá-lo apenas esparsamente. Embora nos países de língua inglesa e secundariamente também na França a questão do fraco desempenho escolar dos meninos, particularmente daqueles pertencentes às minorias étnicas, venha recebendo ampla atenção tanto da mídia e dos governantes quanto da pesquisa acadêmica, nesses países o debate emerge a partir dos resultados de testes padronizados, o que torna menos relevante o estudo das falas, opiniões e avaliações dos professores e professoras. De toda forma, é importante destacar que, nessa polêmica, alguns pesquisadores vêm insistindo na necessidade de considerar simultaneamente o sexo, a raça ou etnia, assim como a classe social, na análise do fracasso escolar, questionando abordagens bipolares que tendem a opor um suposto grupo homogêneo de

${ }^{4} \mathrm{Em}$ texto publicado anteriormente, analisei especialmente os conteúdos de gênero envolvidos nas avaliações dessas mesmas professoras. CARVALHO, M. P. de. Mau aluno, boa aluna? Como as professoras avaliam meninos e meninas. Estudos Feministas, vol. 9, n 2, dezembro de 2001, pp.554-574. 
Marília Pinto de Carvalho

meninos malsucedidos a um conjunto também homogêneo de meninas de sucesso. ${ }^{5}$

As informações aqui utilizadas foram coletadas numa investigação de caráter qualitativo junto às turmas de quarta série numa escola pública de ensino fundamental do município de São Paulo, ao longo do ano de 2000 e início de $2001 .{ }^{6}$ Foram gravadas entrevistas semi-estruturadas com as duas professoras de classe e a orientadora educacional e realizadas observações nas salas de aula regulares, em suas atividades de recuperação, nas reuniões pedagógicas e nos conselhos de classe que diziam respeito às $4^{a} s$ séries. A todas as famílias das crianças do primeiro ciclo foi passado um questionário de caracterização sócio-econômica, que foi respondido por 210 alunos (num total de 241). ${ }^{7}$

${ }^{5}$ Connell, Robert W. Teaching the boys. In: The Men and the Boys. Bekerley, UC Press, 2000, pp.148-176; DuRUT-BELLAT, Marie. Filles et garcons à l'école: approches sociologiques et psycho-sociales (1re partie). Revue Française de Pédagogie, no 109, Paris, dec. 1994, pp.111-141 e La "découverte" de la variable sexe et ses implications dans la sociologie de l'education française contemporaine. Nouvelles Questions Féministes, vol. 15, no 1, Paris, 1994, pp.35-68; EPSTEIN, Debbie et alli. (eds.) Failing Boys? Issues in gender and achievement. Buckingham, Open university Press, 1999. GILBERT, Rob \& GILBERT, Pam. Masculinity Goes to School. London, Routledge, 1998; KIMMEL, Michael. "What About the Boys?": what the current debates tell us and don't tell us about boys in school. Wellesley, MA, Center for Research on Women's $6^{\text {th }}$ Annual Gender Equity Conference, Special Report, january 2000; MAC AN GHAILL, Máirtín. The Making of Men: masculinities, sexualities and schooling. Buckingham, Open University Press, 1995; TerRAIL, Jean-Pierre. Réussite scolaire: la mobilisation des filles. Sociétés Contemporaines, $\mathrm{n}^{\circ} \mathrm{s}$ 11-12, Paris, 1992, pp.53-89; WARRINGTON, Molly \& YOUNGER, Michael. The other side of the gender gap. Gender and Education, vol. 12, n 4 , London, 2000, pp.493-508.

6 Trata-se de uma das etapas de um projeto mais amplo de pesquisa que vem se desenrolando desde 1999, com apoio inicialmente da FAPESP e atualmente do $\mathrm{CNPq}$ e que foi incorporado ao projeto "A gestão da violência e da diversidade na escola" do Programa de Cooperação Internacional Brasil/França (CAPES/COFECUB).

7 Agradeço às alunas Patrícia Martins Penna, Marina Figueiredo e Amélia Artes a colaboração no trabalho empírico. 
Articulações entre gênero e cor/raça

No que tange ao pertencimento racial, foram coletadas informações sobre a cor ou raça atribuídas às crianças das duas classes de quarta série a partir de dois olhares: o das professoras (hetero-atribuição) e o dos próprios alunos (auto-atribuição). ${ }^{8}$ Aos alunos foi aplicado um questionário com duas questões, em abril de 2001, nas salas de aula. A primeira pergunta, aberta, indagava: "Qual a sua cor ou raça?". A segunda pedia que a criança se classificasse dentro de critérios fechados: "Como você se classifica na lista abaixo? (marque apenas um)". As opções apresentadas foram: "branco, pardo, preto, oriental, indígena". ${ }^{9}$ Como havia a intenção de cruzar essas informações com outras obtidas anteriormente, era necessário que elas se identificassem no formulário, o que foi explicado e não encontrou resistências. Também foi explicado o motivo de haver duas questões, uma aberta e outra dirigida; porque utilizar aquelas categorias de classificação (procurando lembrá-los do censo realizado há pouco tempo) e qual o significado de cada uma. Particularmente o termo "pardo" mostrou-se desconhecido dos alunos. Obtivemos 59 questionários respondidos, pois apenas um aluno não compareceu à aula no dia da aplicação. Nenhuma criança se recusou a responder, sendo que apenas duas meninas deixaram em branco a questão aberta, todos responderam à questão dirigida e apenas um menino anulou seu questionário, marcando todos os itens da segunda questão. Contudo, houve diversas interferências nas opções fechadas, que serão analisadas detalhadamente adiante, ao lado da interpretação das respostas livres.

\footnotetext{
8 A classificação feita pelas professoras foi considerada como a mais relevante entre os diferentes olhares externos ao próprio aluno, por representar a classificação institucional e por seu papel decisivo na avaliação do desempenho escolar e na determinação de trajetórias educacionais das crianças.

9 Por engano, foi colocada a opção "oriental" em substituição a "amarelo", utilizada pelo IBGE. As conseqüências desse fato, contudo, foram limitadas e serão analisadas abaixo.
} 
Marília Pinto de Carvalho

Às professoras foi solicitado, em entrevista registrada em caderno de campo, que classificassem um a um os alunos $e$ alunas, utilizando como referência listas fornecidas pela secretaria, nas quais a pesquisadora anotava as respostas. Pedi a elas que utilizassem a classificação por cor, explicitando-lhes previamente as categorias: "branco", "pardo", "preto", "oriental" e "indígena" (ver nota anterior) e explicando que o mesmo seria solicitado aos próprios alunos num questionário por escrito.

\section{$\mathrm{O}$ conceito de raça}

Apesar de não ser o foco inicial dessa pesquisa, que partiu de questões sobre as diferenças de desempenho escolar entre os sexos, a desigualdade racial impôs-se como categoria indispensável à análise, à medida que ficavam evidentes as diferenças no interior do próprio grupo dos meninos e se buscava caracterizar aqueles com problemas escolares. Havia indicações na literatura brasileira ${ }^{10} e$ internacional sobre a relevância do pertencimento étnico-racial nesses processos de diferenciação no interior do mesmo grupo de sexo e elementos empíricos apontando nessa direção. Contudo, um primeiro levantamento indicou que, se há na sociologia da educação brasileira uma razoável bibliografia sobre as diferentes articulações entre classe social e desempenho escolar, herdeira especialmente da corrente francesa que se desenvolveu a partir da obra de Pierre Bourdieu, o mesmo não se pode dizer das desigualdades raciais. Entre as obras que foi possível localizar, destacamos o clássico de Maria Helena Souza Patto ${ }^{11}$, que já apontava o peso do racismo vigente em nossas escolas na produção do fracasso escolar; e a

${ }^{10}$ SILVA, Cármem Duarte et alii. Meninas bem-comportadas, boas alunas, meninos inteligentes, mas indisciplinados. Cadernos de Pesquisa, ${ }^{\circ}$ 107, São Paulo, julho de 1999, pp.207-225; RosEmBERG, F. Educação formal, mulher e gênero... Op. cit.

${ }^{11}$ Patto, Maria Helena Souza. A produção do fracasso escolar: histórias de submissão e resistência. São Paulo, T.A.Queiroz, 1990. 
Articulações entre gênero e cor/raça

coletânea organizada por Fulvia Rosemberg e Regina Pahim Pinto $^{12}$ a partir dos resultados de um seminário realizado em 1986, na qual estão presentes diversos textos seminais dos debates desenvolvidos a partir de então. Na verdade, poucas análises têm sido desenvolvidas combinando gênero e raça ou cor dentro da pesquisa brasileira sobre desempenho escolar. Trata-se aqui, pois, de um esforço inicial para articular as discussões sobre gênero $e$ raça no contexto da produção cotidiana do sucesso/fracasso escolar no ensino fundamental brasileiro.

O conceito de raça aqui adotado é o de "raça social", conforme explicitado por Antônio Sérgio Alfredo Guimarães, isto é, não se trata de um dado biológico, mas de "construtos sociais, formas de identidade baseadas numa idéia biológica errônea, mas eficaz socialmente, para construir, manter e reproduzir diferenças e privilégios". ${ }^{13}$ Para esse autor, se a existência de raças humanas não encontra qualquer comprovação no bojo das ciências biológicas, elas são, contudo "plenamente existentes no mundo social, produtos de formas de classificar e de identificar que orientam as ações dos seres humanos". ${ }^{14} \mathrm{Ou}$, nas palavras de Tereza Cristina Araújo, a raça pode ser concebida como "um fato social, referido aos significados atribuídos pelas pessoas a atributos físicos e que servem para demarcar indivíduos e grupos, como uma percepção social que categoriza". ${ }^{15}$

No contexto brasileiro - e em diversos países da América Latina - a classificação racial se apóia tanto na aparência (características fenotípicas, como a cor da pele ou o tipo de

${ }^{12}$ Rosemberg, Fulvia \& PINTO, Regina Pahim. (orgs.) Raça negra e educação Cadernos de Pesquisa, n 63, São Paulo, Fundação Carlos Chagas, novembro de 1987.

${ }^{13}$ Guimarães, Antônio S. A. Raça e os estudos de relações raciais no Brasil. Novos Estudos Cebrap, n 54, São Paulo, julho de 1999, p.153.

${ }^{14}$ ID., IB.

${ }^{15}$ ARAÚJO, Tereza Cristina N. A classificação de "cor" nas pesquisas do IBGE: notas para uma discussão. Cadernos de Pesquisa, n 63 , São Paulo, Fundação Carlos Chagas, novembro de 1987, p.15. 
Marília Pinto de Carvalho

cabelo) e na ascendência ou origem, quanto no status sócioeconômico da pessoa. Fúlvia Rosemberg destaca que, diferentemente da classificação norte-americana, baseada exclusivamente em regras de descendência, em que o filho de uma pessoa negra é sempre um negro e que gera um sistema rígido e dicotômico, a classificação racial no Brasil é fluida e variável, com a "possibilidade de passagem da 'linha de cor' em decorrência da combinação fenotípica e do status social do indivíduo". ${ }^{16}$ Assim, a cor seria apenas um dos elementos de que se lança mão na construção social das relações raciais. Para Araújo, a cor, no Brasil é "uma metáfora, a categoria mais freqüentemente acionada para demarcar diferenças $e$ desigualdades com base na raça". ${ }^{17}$

Em decorrência disso, utilizo aqui uma classificação por cor, baseada nas categorias usadas pelo IBGE e também seu agrupamento em termos mais propriamente raciais: um grupo de "negros" composto por aqueles classificados como pretos ou como pardos e um de "não-negros", que inclui brancos, indígenas e orientais. ${ }^{18}$

Frente à complexidade do processo de classificação assim constituído, é preciso atentar, como nos indica Araújo, para a situação social específica em que ele se desenrola e que the confere significado:

a percepção social da cor e a escolha e/ou atribuição de categorias de cor é uma operação complexa que envolve não apenas uma apreensão de características fenotípicas, aqui imbuídas de valor e carregadas de significado, mas em

\footnotetext{
${ }^{16}$ Rosemberg, Fulvia. Raça e desigualdade educacional no Brasil. In: AQUiNO, Julio G. (org.) Diferenças e preconceito na escola: alternativas teóricas e práticas. São Paulo, Summus, 1998, p.74.

${ }^{17}$ ARAúJO, T. C N. A classificação de "cor"... Op. cit., p.15.

${ }^{18}$ Devido à presença de alunos de ascendência japonesa e de duas crianças que se auto-classificaram como indígenas, optei pela denominação "não-negros", que me pareceu mais precisa que "brancos".
} 
Articulações entre gênero e cor/raça

que as categorias compõem um sistema e esta operação se processa num contexto de interação social. ${ }^{19}$

Idéias semelhantes estão presentes num interessante estudo de Edward Telles e Nelson $\mathrm{Lim}^{20}$, baseado num survey de âmbito nacional do Instituto Data Folha, de 1995, que incluía tanto a auto-classificação por cor quanto a classificação pelo entrevistador, cuja análise que foi retomada e ampliada posteriormente por Telles. ${ }^{21}$ Essa investigação aponta o quanto critérios "não-físicos", na expressão dos autores, afetam as características raciais dos brasileiros, que devem ser tomadas não como fatos objetivos e inquestionáveis, mas como um sistema cambiante, sujeito à percepção social, na qual o status sócioeconômico tem um peso considerável. Telles chama nossa atenção para o fato de que, apesar da discriminação $e$ desigualdade raciais dependerem da classificação racial feita por terceiros, isso raramente é considerado nas análises sociológicas, sendo a raça normalmente tomada como fixa ou essencial:

Embora a sociologia moderna amplamente aceite a idéia de que o conceito de raça é construído socialmente e é portador de ambigüidades, raramente essa idéia é incorporada na análise sociológica. ${ }^{22}$

Esses autores, além disso, mostram que, ao lado da renda, também tinham influência significativa no "embranquecimento" ou "escurecimento" das pessoas, a escolaridade, a região

${ }^{19}$ Araúso, T. C N. A classificação de "cor"... Op. cit., p.15

${ }^{20}$ TELLES, Edward e LiM, Nelson. Does it matter who answers the race question? Racial classification and income inequality in Brazil. Demography, vol. 35, n 4 , novembro de 1998, pp.465-474.

${ }^{21}$ Telles, Edward. Racismo à brasileira: uma nova perspectiva sociológica. Rio de Janeiro, Relume Dumará/Fundação Ford, 2003.

${ }^{22}$ ID., IB., p.113. 
fisiográfica do país e a moradia em zona urbana ou rural. ${ }^{23}$ Por outro lado, Edith Piza e Fulvia Rosemberg ${ }^{24}$, comentando o mesmo survey do Instituto Data Folha, lembram que também deve ser considerada a cor ou raça dos entrevistadores, já que se trata de uma relação, e lamentam que não haja dados disponíveis a respeito, embora se afirme que eram em sua maioria brancos $e$ de média ou alta escolaridade.

Essas reflexões, desenvolvidas para pensar a escala macro das estatísticas colhidas através de pesquisas quantitativas, parecem ser também extremamente úteis em escala cotidiana, qualitativa. Trabalhar no contexto de uma escola, mais particularmente junto a duas classes de $4^{\text {a }}$ série do ano de 2000 , totalizando 60 alunos e duas professoras, permitiu uma ênfase especial na produção de significados associados a características fenotípicas e a atribuições raciais, assim como nas inter-relações através das quais emergiam as classificações de cor e de raça. Não se tratava de encontrar "a verdadeira cor" de uma criança, nem de minimizar as discrepâncias entre diferentes classificações, mas, ao contrário, o interesse maior foi localizar e qualificar essas diferenças e tentar apreender os significados escolares e de gênero que se articulavam à categorização racial.

Ao longo de toda a pesquisa, procurei perceber o que as professoras consideravam fundamental avaliar nos alunos $e$ alunas, como o faziam e em que medida suas opiniões sobre masculinidade e feminilidade $e$ sobre as relações raciais interferiam nesses julgamentos. Nem sempre o que apreendi foram preconceitos ou estereótipos explícitos, mas sutis interpenetrações entre opiniões estereotipadas e julgamentos profissionais bem fundamentados, cujos efeitos se ampliavam na medida da falta de critérios de avaliação objetivos e explicitados

${ }^{23}$ ID., IB., p.470.

${ }^{24}$ PizA, Edith e Rosemberg, Fulvia. Cor nos censos brasileiros. In: CARONE, I. e BENTO, M. A. S. Psicologia social do racismo: estudos sobre branquitude $e$ branqueamento no Brasil. Petrópolis-RJ, Vozes, 2002, p.104. 
Articulações entre gênero e cor/raça

coletivamente pela equipe escolar. Assim, apresento a seguir um quadro geral da escola investigada e de como ali se fazia a avaliação dos alunos.

\section{O contexto escolar}

A escola estudada atende a 670 alunos do ensino fundamental e médio, em dois períodos de funcionamento: das 7:30 às 12 horas, estudam os jovens de $6^{\mathrm{a}}$ série do fundamental até $\mathrm{o} 3^{\circ}$ ano do médio; e das 13 às 17 horas, as crianças de $1^{\mathrm{a}}$ a $5^{a}$ série do ensino fundamental. São quarenta professores e professoras, todos com curso superior e quase todos com jornada de quarenta horas semanais, com um máximo de vinte horas em sala de aula e as demais voltadas a reuniões, preparação de aulas $e$ aperfeiçoamento profissional. A equipe técnica conta com duas orientadoras educacionais e uma coordenadora pedagógica, além de diretor e vice-diretor; e os serviços de apoio operacional e secretaria dispõem de um total de 26 funcionários. O prédio é grande, arejado e espaçoso, embora apresente problemas de conservação que chegam a comprometer o uso de determinados espaços.

Como se pode depreender, apesar de pertencer à rede pública, essa escola apresenta características próprias e condições de funcionamento particularmente adequadas. Todas as classes contam com trinta alunos e mesclam crianças provenientes de setores populares, médios e médios intelectualizados, abrangendo um grupo bastante heterogêneo em termos sócio-econômicos, étnico-raciais e culturais, particularmente se comparada à homogeneidade que em geral se encontra, numa cidade como São Paulo, tanto nas escolas públicas de periferia, quanto nas escolas particulares de elite.

Aqui teremos em foco especialmente as duas classes de quarta série, num total de 60 alunos, atendidos por duas professoras, que dividiam entre si as disciplinas: Célia, responsabilizando-se por Matemática e Ciências, e Laís, que 
ensinava Português, História e Geografia. ${ }^{25}$ Ambas as professoras tinham curso superior de Pedagogia, sendo que Célia cursava, em 2000, mestrado em Educação, na área de ensino de ciências. Eram jovens, com 26 e 27 anos, tinham pequena experiência profissional e estavam naquela escola há dois anos, no caso de Laís e há três no de Célia. Solicitadas a se auto-classificarem de acordo com os critérios de cor do IBGE, Célia classificou-se como branca e Laís como parda, embora para a pesquisadora ambas se enquadrassem na categoria "branco".

A escola em questão adotou, a partir de 1999, o sistema de avaliação por conceitos - "PS" (plenamente satisfatório), "S" (satisfatório) e "NS" (não satisfatório) - com dois ciclos no ensino fundamental (de $1^{\mathrm{a}}$ a $4^{\mathrm{a}}$ e de $5^{\mathrm{a}}$ a $8^{\mathrm{a}}$ séries). Existe um sistema de recuperação paralela ao longo de todo o ano, chamado de "oficinas de reforço", que são oferecidas pela própria professora de classe nas primeiras séries ou da matéria, nas séries finais. No caso das séries iniciais, que estudamos, essas oficinas ocorriam pela manhã, uma vez por semana, com duração de duas horas $e$ meia. Célia e Laís atendiam a grupos diferentes de alunos das duas classes de quarta série, conforme tivessem dificuldades em português ou matemática (ou em ambas). De acordo com elas, eram as professoras que indicavam os alunos para o reforço. Alguns permaneciam durante todo o ano, enquanto outros, que apresentavam dificuldades específicas, eram atendidos por períodos variáveis e depois dispensados. Elas indicavam para o reforço tanto alunos classificados com conceito "NS", quanto alunos que obtinham "S", mas "estavam cambaleando", na expressão de Célia.

Como professoras de quarta série, encerramento do primeiro ciclo, elas deveriam decidir, ao final do ano letivo, se algum aluno seria reprovado, e comentaram em entrevista suas dificuldades frente a esse quadro. Embora Laís revelasse mais dúvidas quanto ao uso dos conceitos, ambas pareciam ter

${ }^{25}$ Todos os nomes de pessoas e instituições são fictícios. 
Articulações entre gênero e cor/raça

problemas, especialmente com os alunos intermediários, aqueles que deveriam ser classificados como " $\mathrm{S}$ ":

Eu me sinto muito perdida com esses três conceitos. (...) Porque para mim, Laís, não satisfatório é uma pessoa que não faz, se recusa a fazer. Não quer fazer, não se envolve em hipótese alguma, não entregou, não fez. (...) Para mim, o NS é nulo. A partir do momento que você se propôs a ler um texto, se propôs a tentar responder alguma coisa, pelo menos essa sua atitude já é satisfatória. Mas aí, é satisfatório para esse tamanho [gesto de pequenez]. É muito complicado...

na verdade, três conceitos é muito pouco para a gente estar avaliando. São muitas crianças, eles são muito diferentes. Três conceitos não é nada. E às vezes você tem um $\mathrm{S}$, que é uma criança muito boa mas que ainda não está Plenamente Satisfatória. E você tem muitas vezes um outro $S$ que é aquela criança que saiu do NS e que está entrando. A distância é muito grande. (...) Acho que às vezes a gente é muito... muito injusto com algumas crianças até. (Célia)

Quanto à reprovação ao final do ano, Laís mostrou-se particularmente insatisfeita, indicando a dificuldade em avaliar os alunos sem avaliar simultaneamente a própria escola:

o que a quinta série espera dos nossos alunos? O que uma quinta série dessa escola espera desses alunos? A partir daí, a quinta série - a escola - está estruturada para saber o que quer, o que espera, para estabelecer certos limites de quem pode freqüentá-la ou não? Eu acho que não está, porque se a escola inteira... se eu sinto falta de uma linha [de trabalho comum] de primeira à quarta [séries], como é que eu posso decidir se eles estão aptos ou não para a quinta? Eu acho que para mim é um conflito muito grande, inclusive eu não concordo com a questão da reprovação, ah, em momento algum. [ri] (Laís, ênfase na fala) 
Marília Pinto de Carvalho

Embora Laís afirmasse a falta de critérios comuns de trabalho pedagógico e de avaliação no conjunto da escola, reivindicando maior discussão coletiva sobre o tema, pelo menos seu discurso e o de Célia tinham muitos pontos em comum, com certas diferenças de ênfase. Ambas afirmavam avaliar os alunos a partir de uma multiplicidade de instrumentos (trabalhos individuais sem consulta, do tipo "prova", trabalhos em grupo feitos em classe e em casa, participação nas aulas, lições de casa etc.). E diziam levar em conta tanto o desempenho propriamente dito, quanto o que chamavam de "compromisso do aluno" ou "relação da criança com o cotidiano da escola". Nas palavras de Célia:

$\mathrm{Eu}$ acho que entra toda essa coisa do compromisso, a responsabilidade, eu acho que tá tudo envolvido. (...) Eu acho que tá tudo muito misturado, é muito difícil, acho, a gente separar essas coisas. Muitas vezes, talvez, a falta de compromisso da criança influencie bastante no fato dela não conseguir alcançar aqueles objetivos. Mas a gente tem outras crianças que são supercompromissadas e que mesmo assim não conseguem alcançar minimamente os objetivos. (Célia, ênfase na fala)

A percepção da importância do comportamento disciplinado como critério de avaliação utilizado pelas professoras, levou-nos a considerar no grupo de crianças "com problemas escolares" aquelas com conceitos "NS" (não satisfatório), as indicadas para as "oficinas de reforço" e também as que haviam recebido algum tipo de punição formal, conforme registrado em seus prontuários na secretaria da escola (advertência ou suspensão). Assim, no contexto dessa pesquisa, o desempenho escolar da criança referese tanto a seu rendimento propriamente acadêmico quanto a seu comportamento frente às regras escolares. ${ }^{26}$

${ }^{26}$ Essa co-existência de critérios era bastante clara para as crianças, para quem o que caracterizava um bom aluno naquela escola era antes seu comportamento que sua aprendizagem: "Ele [o bom aluno] faz todas as lições, não responde para 
Articulações entre gênero e cor/raça

Perguntadas sobre as razões das dificuldades escolares de algumas crianças, Laís e Célia percorreram caminhos bastante diversos em suas explicações. Laís remeteu-se imediatamente aos problemas internos de funcionamento da escola, afirmando que, sem dúvida, os problemas de aprendizagem e reprovação ali eram menores que na maioria das escolas públicas, eram "mais amenizados", mas que os profissionais ainda enfrentavam dificuldades no sentido de articular uma linha pedagógica comum:

A proposta pedagógica ainda é muito isolada, inclusive é uma exigência muito grande dos pais aqui da escola, que existisse continuidade. Eu me sinto como se fosse assim, metaforicamente, uma linha que emendasse as pérolas, sabe? Assim, as pérolas estão meio espalhadas, que às vezes dá a sensação de estar remando contra a maré, de estar cada um correndo para um lado. Em dados momentos o grupo de primeira a quarta se sente assim $e$ coloca essa dificuldade nessa questão da linha. (Laís)

Coerentemente, ao discutir a avaliação, Laís, como vimos, falou dessas mesmas dificuldades de um trabalho coletivo em continuidade, criticando a falta de critérios para avaliar e para reter alunos na quarta série.

Já Célia respondeu à pergunta sobre as dificuldades de desempenho escolar entre os alunos de $1^{\mathrm{a}}$ a $4^{\mathrm{a}}$ séries, remetendo a questão às famílias:

Eu acho assim, não há um motivo principal. Eu acho que tem um conjunto de motivos em volta. Uma coisa que eu sinto muita falta - eu estou falando por mim - o que eu sinto muita falta é o apoio da família. A gente tem muitos casos de alunos em que você chama a família, a família lava as mãos. (...) Então eu acho que essa parceria família-

a professora e faz tudo que ela quer" (André). Só secundariamente algumas crianças mencionaram como critérios "estudar para a prova" e "tirar nota boa" (Ana). 
Marília Pinto de Carvalho

escola é muito importante. E muitas vezes a gente não encontra esse respaldo na família. (Célia, ênfase na fala)

Perguntadas diretamente se percebiam maiores dificuldades entre as crianças negras nessa escola, enquanto Laís respondeu que não, Célia disse que sim, ponderando a seguir:

Dificuldades de disciplina ou de aprendizagem? Não tenho elementos para pensar a escola inteira, mas nessa turma [quarta série de 2000] há, sim, mais problemas de disciplina, comportamentos, atitudes.

Para a professora, essas dificuldades estariam relacionadas ao

histórico da família desses alunos, alunos que moram em ambientes mais pobres, favelas, estão mais expostos a coisas cruéis, os modelos de adultos que essas crianças têm são pessoas mais rudes.

Quando perguntei se, então, seria mais decisiva a situação sócio-econômica que a cor, ela respondeu que sim, "porque você vê também alunos brancos pobres com as mesmas características". De acordo com Rosemberg, essa concepção bastante difundida na intelectualidade brasileira - é herdeira das análises desenvolvidas nos anos 50 pela chamada "Escola de São Paulo", especialmente nos trabalhos de Florestan Fernandes, e marca profundamente o pensamento educacional brasileiro que:

ao reconhecer a concentração maciça do alunado negro nas camadas mais pobres da população, tende a identificar as dificuldades interpostas à escolaridade da população negra com os problemas enfrentados pela pobreza, não considerando a especificidade do pertencimento racial. ${ }^{27}$

${ }^{27}$ RoSEMBERG, F. Raça e desigualdade educacional no Brasil. Op. cit., p.74. 
Articulações entre gênero e cor/raça

Ambas as professoras afirmaram não haver discussão organizada a respeito da desigualdade racial entre as profissionais de $1^{\mathrm{a}}$ a $4^{\mathrm{a}}$ séries da escola. Junto aos alunos, o tema viria à tona apenas esporadicamente, em aulas de Estudos Sociais, nas discussões sobre a escravidão e os quilombos, citando casos em que alunos teriam trazido de casa material interessante fornecido por seus pais ou mães, militantes de movimentos negros.

Quando se tratava da diferença sócio-econômica, o silêncio prevalecia no conjunto das educadoras do primeiro ciclo. Atendendo a crianças de origens sociais bastante diversificadas, as educadoras tendiam a afirmar a neutralidade de suas ações $e$ avaliações, insistindo na heterogeneidade das turmas, na ausência de testes seletivos para ingresso na primeira série e enfatizando a imparcialidade dos critérios de avaliação. Contudo, através do questionário respondido pelas famílias, pudemos constatar que enquanto metade dos alunos de $1^{\mathrm{a}}$ a $4^{\mathrm{a}}$ séries vinham de famílias com renda familiar superior a dez salários mínimos, entre os alunos em recuperação esse índice caía para 21\% (11 alunos em $52)^{28}$

No que se refere à diferença de desempenho escolar entre os sexos, não encontramos dificuldade no reconhecimento da questão, ao apresentar a proposta da pesquisa à equipe de orientação escolar e em reunião com o conjunto de professores e professoras. O tema foi identificado como merecedor de reflexão, na medida em que havia certa concordância de que os meninos apresentariam maiores problemas, mas também foi relatado que não havia qualquer discussão acumulada a esse respeito.

No caso das duas professoras de quarta série, era nítida a diferença de percepção quando se tratava dessa diferença entre os sexos. Enquanto Laís respondeu prontamente à pergunta se havia alguma característica comum no grupo de alunos com dificuldades

\footnotetext{
${ }^{28}$ Os números absolutos nessa pesquisa são pequenos e não têm pretensão de representatividade estatística. Utilizamos porcentagens arredondadas com o único objetivo de facilitar comparações.
} 
Marília Pinto de Carvalho

escolares, dizendo que "o número de meninos é maior e vai se acentuando [de uma série para outra]"; Célia voltou a mencionar as "famílias desinteressadas". Essa diferença de percepção pode estar articulada a uma visão mais crítica das relações de gênero no discurso de Laís, que chegou a freqüentar disciplina a respeito durante seu curso superior. Ela mostrou estar atenta à questão, particularmente frente às pesquisadoras, ao comentar sua classe de 2001: "Esse ano, toda segunda-feira, eu lembro de você: tenho sete no reforço e os sete são meninos".

É nesse contexto, portanto, que devem ser interpretadas as falas e posturas dessas professoras e de seus alunos, assim como as desigualdades institucionais (desempenho acadêmico e punições disciplinares) que verificamos. Um contexto de silêncio sobre as questões de classe, raça e gênero, algo que se conhece mas não se discute organizadamente, dificilmente se nomeia, embora incomode - ou exatamente porque incomoda.

$\mathrm{Na}$ literatura educacional, a discussão sobre as razões do fracasso escolar é antiga e profícua e tem freqüentemente oscilado entre os dois pólos expressos nas falas de Laís e Célia: a culpabilização das famílias e a busca de causas intra-escolares. A complexificação do debate, contudo, vem indicando que múltiplas dimensões interferem nesse processo e que é preciso levar em conta tanto as condições sócio-econômicas e culturais de origem da criança, quanto as condições de funcionamento das escolas, o preparo dos professores, os critérios de avaliação, etc. ${ }^{29} \mathrm{O}$ que essa literatura não tem abordado com a devida profundidade é o fato de que, no grupo daqueles que fracassam na escola, ou frente aos quais a escola fracassa em ensinar, os meninos são em

\footnotetext{
${ }^{29}$ AqUINO, Julio Groppa. (org.) Erro e fracasso na escola: alternativas teóricas e metodológicas. São Paulo, Summus, 1992; ARROYO, Miguel. Fracasso/sucesso: um pesadelo que perturba nossos sonhos. Programa de correção de fluxo escolar. Cadernos em Aberto, no 17, Brasília/INEP, janeiro de 2000; PARO, Vitor Henrique. Reprovação escolar: renúncia à educação. São Paulo, Xamã, 2001; PATTO, M. H. S. A produção do fracasso escolar... Op. cit.
} 
Articulações entre gênero e cor/raça

número maior que as meninas e dentre os meninos, os negros em maior proporção que os brancos.

$\mathrm{Na}$ escola estudada, entre os 52 alunos de $1^{\mathrm{a}}$ a $4^{\mathrm{a}}$ série, atendidos em algum momento de 2000 nas oficinas de reforço, 20 eram meninas enquanto 32 eram do sexo masculino. Isso significa que $21,5 \%$ do total de 241 alunos haviam passado pelas oficinas, sendo $16 \%$ do total de meninas, frente a $28 \%$ de todos os meninos.

Em particular nas duas classes de quarta série, dos 60 alunos, 13 estiveram nas oficinas de reforço ao longo do ano, sendo nove meninos e quatro meninas. Considerando-se que eram ao todo 35 crianças do sexo feminino e 25 do sexo masculino, temos que $11 \%$ de todas as meninas da quarta série foram indicadas para as oficinas, enquanto o mesmo ocorreu com $36 \%$ dos meninos. Nessas classes, 17 crianças foram classificadas pelas professoras como "negras" (pretas ou pardas), sendo que sete delas freqüentavam o reforço (uma proporção de $41 \%$ ) e seis tiveram problemas disciplinares (35\%). Já entre as 34 crianças classificadas como "não negras" (orientais e brancas, já que nenhuma criança foi classificada como "indígena" pelas professoras), seis estavam no reforço (17\%) e apenas uma teve problemas de disciplina.

Como explicar essas diferenças? Tentemos ir um pouco mais a fundo nos critérios de avaliação de nossas professoras $e$ nas suas idéias sobre as relações raciais.

\section{Constrangimentos $e$ subjetividade}

Tanto Célia quanto Laís manifestaram incômodo com as categorias "preto" e "pardo": "Sempre aprendi 'academicamente' a não falar preto, falar negro" (Laís). Ao fazer a classificação, Célia usou o tempo todo os termos "negro", "pardo", "branco" e "oriental". Depois de perguntar-lhe por duas vezes se era "preto" que ela queria dizer ao falar "negro", anotei "negro" diante dos 
Marília Pinto de Carvalho

nomes que ela assim classificou, mas, ao tabular os dados, considerei essas indicações como equivalentes a "preto".

As maiores dúvidas, também para ambas, pareciam ser quanto à classificação de crianças pardas. As professoras oscilavam tanto entre branco e pardo, quanto entre pardo e preto:

se eu classifiquei a M. de branca, agora coloco a outra como parda... Pensei: "elas têm a mesma cor de pele" (Laís); Isso é muito difícil aqui em São Paulo. Os orientais é mais fácil, até o nome já indica (Célia).

Efetivamente, as professoras foram mais rápidas e tiveram poucas dúvidas nas indicações de "orientais".

De toda forma, havia algo de constrangedor para ambas as professoras ao fazer a classificação por cor, evidenciando os significados negativos embutidos nas características associadas ao pertencimento à raça negra. Além disso, nos termos propostos, essa classificação envolvia palavras com sentido que elas percebiam como pejorativo, tais como "preto" e "pardo", que elas hesitavam em atribuir a "suas" crianças. Mas também parecia que elas se davam conta, naquele momento, de alguma coisa nova $e$ ao mesmo tempo desagradável, como expressou Laís ao final da entrevista: "Puxa, nunca mais vou olhar esses meninos do mesmo jeito depois disso!".

Célia demonstrou bastante clareza quanto ao caráter subjetivo e variável desse tipo de classificação, remetendo-se a sua experiência em Salvador, na Bahia, para onde se mudou com a família quando era adolescente. Lá, ela teria sentido o "preconceito ao contrário", sendo chamada de "azulona, cor de parede, branquela": "cheguei a ficar tomando sol pra ver se escurecia". Na classe em que estudava então, de $7^{\text {a }}$ série, havia apenas mais três pessoas que se consideravam brancas: "os outros eram negros ou pardos, mas todos se assumiam como negros, se afirmavam, havia essa diferença cultural com São Paulo". Assim, essa professora parecia ter razoável percepção das complexidades 
da classificação por cor ou raça. ${ }^{30}$ Laís, por sua vez, ao se classificar como parda, relatou que sua família se compunha de dois ramos bem definidos, um proveniente do nordeste, com pessoas que ela considerava pardas e outro de imigrantes espanhóis, de pele muito clara. Nessa comparação, ela se incluiu no ramo pardo da família e, em conversa, alguns dias depois, relatou que o tema gerara polêmica entre seus familiares, sempre dando a impressão de que se tratava de uma questão nova para ela. De toda forma, devemos assinalar que Laís era percebida $e$ tratada na escola como branca.

A subjetividade da classificação por cor, no nosso contexto, pode ser bem exemplificada através das diferenças encontradas na classificação feita por cada uma das professoras. Entre 60 alunos, dez foram classificados diferentemente, sendo que em oito casos, a divergência se deu entre pardo e branco, sete deles referentes a crianças do sexo feminino, pois uma das professoras, Célia, não classificou qualquer menina como parda. Assim, sete crianças do sexo feminino classificadas por ela como brancas, apareceram para sua colega como pardas. Sabendo do tom pejorativo da palavra pardo, pareceu-nos que, para aquela professora, atribuí-la às meninas era ainda mais constrangedor do que aos meninos, fenômeno também verificado por Telles ${ }^{31}$ entre os entrevistadores da pesquisa Data Folha, embora com maior ênfase para a categoria "preto".

Quando, além das professoras, consideramos também a auto-classificação feita pelas crianças, o quadro se torna mais complexo. Levando em conta apenas as respostas dirigidas, 26 crianças se classificaram como brancas, 17 como pardas, dez como pretas, três como orientais e duas como indígenas (Tabela 1). No grupo de oito alunos de ambos os sexos sobre os quais as professoras divergiram entre si entre pardo e branco, três

${ }^{30}$ Edward Telles, entre outros, enfatiza as diferenças nos sistemas de classificação racial por regiões, no Brasil. TELLES, E. Racismo à brasileira... Op. cit., p.126.

31 TELLES, E. Racismo à brasileira... Op. cit., p.125. 
Marília Pinto de Carvalho

concordaram com o "branco", os demais cinco classificando a si mesmos como pardos ou pretos.

Entre as 58 crianças que fizeram a auto-classificação dirigida, 26 divergiram de pelo menos uma das professoras, o que me parece um indicador muito forte da variabilidade desses conceitos. Na pesquisa Data Folha, anteriormente citada ${ }^{32}$, houve inconsistência entre a auto e a hetero classificação em $21 \%$ da amostra, com a mesma tendência dos entrevistadores a "clarearem" os entrevistados tomados em conjunto. No nosso caso, considerando as duas professoras e a auto-atribuição, as discrepâncias de classificação se distribuem igualmente entre meninos (13) e meninas (13); e a maior parte dessas diferenças (17) se localiza entre as crianças que se classificaram como pardas, sendo treze percebidas ao menos por uma professora como brancas.

A tendência das professoras a "branquearem" seus alunos fica mais evidente se agruparmos essas categorias de cor em grupos raciais: "negros" (pretos e pardos) e "não negros" (brancos, orientais e indígenas). Enquanto 31 crianças se autoclassificaram como não negras, 27 o fizeram como negras. Já para Célia, havia 44 crianças não negras no grupo, e apenas 16 negras; e para Laís, 37 não negras e 23 negras (Tabela 2). ${ }^{33}$ Esse fenômeno pode estar sendo influenciado pelo fato de ambas as professoras serem brancas, pois há indicações na literatura de que professoras negras tenderiam menos a "embranquecer" seus alunos. ${ }^{34}$ Mas de toda forma, a idéia de que era constrangedor para as professoras, ou até mesmo ofensivo, classificar as crianças como pardas ou pretas aparece como explicação possível para esse

${ }^{32}$ TELLES, E. e LiM, N. Does it matter who answers the race question?... Op. cit.; TELLES, E. Racismo à brasileira... Op. cit.

${ }^{33}$ Nenhum aluno ou aluna foi classificado como indígena pelas professoras, mas um menino e uma menina o fizeram na auto-classificação.

${ }^{34}$ OlivelRA, Eliana de. Relações raciais nas creches diretas do município de São Paulo, São Paulo, Dissertação de Mestrado, PUC-SP, 1994. 
Articulações entre gênero e cor/raça

branqueamento frente à auto-percepção dos próprios alunos e alunas.

\section{Crianças com dificuldades escolares}

Esse constrangimento, contudo, parecia ser menor quando se tratava das crianças com algum tipo de dificuldade na escola, sejam aquelas indicadas para reforço, sejam aquelas que tinham problemas de comportamento. Como vimos, a partir das dificuldades indicadas pelas próprias professoras em estabelecer critérios de avaliação precisos, que separassem com maior clareza problemas disciplinares de problemas de aprendizagem, passamos a considerar em conjunto as crianças com problemas de ambas as ordens. A imbricação desses problemas fica clara, por exemplo, tomando-se o conjunto dos alunos de sexo masculino que foram indicados para atividades de reforço. Esse grupo era composto por dois tipos diferentes de meninos: três com conceitos "Não Suficiente" ("NS"), classificados pelas professoras como "apáticos" $e$ nos quais elas identificavam com nitidez problemas de aprendizagem; e mais seis garotos, quatro dos quais haviam recebido pelo menos uma advertência ou suspensão no ano de 2000, todas elas relacionadas à agressão física contra colegas. ${ }^{35}$ Esses últimos seis alunos tinham conceitos "Suficiente" ("S") em seus registros e eram considerados medianos em seu desempenho acadêmico, mas mesmo assim participaram durante todo o ano letivo das "oficinas de reforço". ${ }^{36}$

Ao todo, 16 crianças apresentavam problemas disciplinares ou de aprendizagem (13 foram em algum momento indicadas para o reforço e sete sofreram punições formais, sendo que quatro delas estão presentes nos dois grupos). Se considerarmos os grupos raciais ("negros" $e$ "não negros"), não houve diferença

\footnotetext{
${ }^{35}$ Um dos demais veio a receber punição formal nos primeiros meses de 2001.

${ }^{36}$ Essa questão está melhor desenvolvida em artigo anterior. CARVALHO, M. P. de. Mau aluno, boa aluna? Op. cit.
} 
Marília Pinto de Carvalho

entre as classificações de Célia e de Laís para quaisquer desses alunos, em comparação com nove discrepâncias entre elas para o conjunto das classes (Tabela 3). Essa consistência entre as classificações das professoras pode ser correlacionada ao fato de termos uma grande maioria de meninos entre as crianças com problemas escolares (5 meninas e 11 meninos), já que a maior parte das diferenças de classificação entre professoras se refere a meninas (oito, num total de nove).

Advertências e suspensões foram atribuídas a seis meninos e apenas uma menina da quarta série em 2000, dos quais seis eram crianças percebidas como negras (pretas e pardas) e apenas um garoto branco (classificação das professoras). Cinco deles provinham de famílias com renda mensal inferior a dez salários mínimos, um não informou e apenas um declarou renda familiar alta. Destaque-se novamente que, dentre estas sete crianças, quatro estavam também nas oficinas de reforço.

Houve igualmente grande consistência entre as hetero $e$ as auto-classificações dentro do grupo de alunos com problemas escolares: se excluirmos os dois alunos que não responderam ao questionário $^{37}$, temos respostas coincidentes entre aluno $e$ professoras em 13 dos 14 casos restantes. Essa situação parece indicar que o desempenho escolar (incluindo aprendizagem $e$ comportamento considerados adequados) é uma referência na determinação do pertencimento racial, referência forte o bastante para ser incorporada à própria identidade racial de alunos $e$ alunas, pelo menos ao final de no mínimo quatro anos de escolarização, como era o caso de nossas classes.

Uma comparação ponto a ponto entre as classificações de cor feitas pelas professoras indica da mesma forma a existência de situações duvidosas em que a decisão parece ter sido tomada tendo como referência entre outros elementos o desempenho escolar da criança. Pelo menos num caso, dois alunos classificados como pardos por Laís e pelas pesquisadoras foram classificados

${ }^{37} \mathrm{Um}$ aluno estava ausente e outro anulou sua resposta. 
Articulações entre gênero e cor/raça

diferentemente por Célia: um deles, que foi mencionado como "excelente aluno", como branco; e o outro, que participava das oficinas de reforço, como preto ("negro", nas palavras da professora).

Assim, uma possível explicação seria que, pelo menos no âmbito da escola, a identidade racial das crianças seria construída tendo como referência não apenas características fenotípicas $e$ status sócio-econômico, mas também seu desempenho escolar. No âmbito da instituição, a classificação de raça seria influenciada pela existência ou não de problemas escolares (disciplinares ou de aprendizagem), considerados como parte constituinte do status da criança, com uma forte articulação entre pertencimento à raça negra e dificuldades na escola.

Após lerem os resultados das primeiras análises do conjunto do material empírico levantado, as professoras Laís e Célia demonstraram tristeza e muita raiva. Disseram não se identificar com o texto e que, apesar de valorizarem a prática de devolução dos resultados aos sujeitos da pesquisa, tinham hesitado muito em discutir o material, tamanha sua revolta. Depois de algum tempo de conversa, contudo, concluí que sua raiva decorrera mais dos acertos que dos erros da análise. Trata-se de duas jovens $e$ comprometidas professoras, sérias em seu trabalho pedagógico $e$ que, além disso, revelaram-se corajosas e perspicazes ao longo de todo esse processo. Mas se elas não eram abertamente preconceituosas nem discriminadoras, se gostavam de seus alunos $e$ se dedicavam a eles, como suas avaliações revelaram-se tão marcadas por hierarquias de gênero, classe e raça?

Como vimos, ao apresentarem em entrevistas seus critérios de avaliação, ambas as professoras afirmaram considerar tanto a aprendizagem quanto o que chamavam de "compromisso da criança com o cotidiano da escola". Através da avaliação desse compromisso eram considerados elementos ligados às atitudes $e$ comportamentos de forma tão decisiva quanto o desempenho mais estritamente acadêmico. Avaliar esses comportamentos, porém, era uma tarefa extremamente subjetiva, mesmo numa 
Marília Pinto de Carvalho

escola razoavelmente estruturada e com espaços coletivos de discussão como aquela. Para fazê-lo, as professoras tinham que lançar mão de repertórios e referências pessoais, apenas relativamente conscientes, sem perceber integralmente seu caráter arbitrário, sem escolhê-los e controlá-los inteiramente.

Seguindo Phillippe Perrenoud, podemos afirmar que no complexo processo que é a relação pedagógica, a racionalidade é apenas ilusória, sendo inevitável "uma erupção de valores, de subjetividade, afetividade" e um certo grau de dependência frente a interesses e preconceitos. O professor enfrenta as diferentes situações de seu cotidiano profissional, entre elas a avaliação dos alunos, "a partir do conjunto de esquemas mais ou menos conscientes de que dispõe, esquemas de ação mas também de percepção, de avaliação, de pensamento".$^{38}$ Não se trata de uma culpa individual, como vivenciado por Laís e Célia ao ler os textos, mas de uma responsabilidade coletiva, quando não se enfrenta o preconceito $e$ não se procura mudar os valores $e$ as predisposições adquiridos no processo de socialização e que estão também presentes na cultura escolar.

Nesse repertório de valores, as idéias e os símbolos socialmente construídos de masculinidade e feminilidade, assim como de negritude e "branquitude" 39 estariam presentes, tanto quanto outras hierarquias ligadas à estrutura sócio-econômica. Se já são ativas e marcantes em sistemas de avaliação escolar mais formalizados, ligados à realização de testes, à atribuição de notas e à organização da escola em séries, essas hierarquias parecem tornar-se ainda mais poderosas nas chamadas "avaliações de processo", associadas aos sistemas de ciclos e não-repetência, particularmente pela subjetividade e indefinição de critérios que costumam cercar a adoção desse tipo de mudança da forma como

\footnotetext{
${ }^{38}$ PeRRENOUd, Philippe. Práticas pedagógicas, profissão docente e formação: perspectivas sociológicas. Lisboa, Dom Quixote/ Instituto de Inovação Educacional, 1993, p.23.

39 O termo "branquitude" vem sendo utilizado como tradução de "whiteness".
} 
Articulações entre gênero e cor/raça

vem ocorrendo. Assim, se essas alterações foram pensadas exatamente para minimizar o caráter seletivo e excludente de nossas escolas, a maneira como vêm sendo implantadas, porém, parece estar ampliando a influência, sobre a vida escolar, de hierarquias sociais mais amplas presentes na sociedade brasileira. Por isso, mais do que em qualquer outro momento, pensar os processos de avaliação dos alunos no sistema escolar brasileiro hoje requer refletir sobre as relações sociais de classe, gênero e raça que informam nossas concepções de bom aluno, aprendizagem, avaliação, disciplina e infância.

\section{As crianças negras}

Dezessete crianças foram categorizadas por ambas as educadoras como negras (pretas ou pardas), sendo 11 meninos e seis meninas. Entre as do sexo feminino, uma teve problemas disciplinares e outra esteve no reforço. Houve consistência entre hetero e auto-classificação para essas seis meninas, talvez pelo fato das professoras indicarem menos crianças do sexo feminino como negras em comparação com os meninos, excluindo assim os casos de maior ambigüidade nos traços físicos.

Dos 11 meninos classificados por ambas as professoras como negros, oito tinham problemas com a escola: dois tiveram apenas punições disciplinares, três estavam no reforço $e$ outros três sofreram punições e também participaram do reforço. Oito deles concordavam com a classificação das professoras, dois não responderam e apenas um discordou. Destaquemos que eram ambas negras as crianças com problemas disciplinares $e$ ao mesmo tempo destacadas como boas alunas nos aspectos ligados à aprendizagem: um menino e uma menina, sendo ela a única do sexo feminino com problemas disciplinares.

As tabelas 3 e 4 são reveladoras: enquanto $59 \%$ das crianças percebidas como negras por ambas as professoras apresentavam algum tipo de problema escolar, essa proporção é de apenas $33 \%$ quando considerada a auto-classificação dos alunos (26,5\% do 
total das classes tinha problemas escolares). Considerando que os dois alunos que não responderam ao questionário haviam sido classificados pelas educadoras como negros, tendo ambos recebido punições e simultaneamente indicação para o reforço escolar, é possível concluir que a grande diferença na proporção de negros com problemas escolares em cada tipo de classificação decorre do fato de as professoras classificarem um número muito menor de crianças como negras. Assim, na classificação das educadoras, a coincidência entre raça negra e problemas escolares é muito mais intensa que na auto-classificação dos alunos.

Ora, sabemos que as professoras tenderam a "embranquecer" ou a divergir quanto à classificação mais no caso das meninas do que dos meninos, o que resulta numa composição sexual marcadamente masculina dentro do grupo classificado por elas como negros (11 meninos e seis meninas). Assim, acabam por coincidir raça negra, masculinidade e problemas escolares, à medida que as meninas têm menos dificuldades com a escola e ao mesmo tempo são classificadas em menor número como negras. A esse quadro, devemos acrescentar que entre os 16 alunos e alunas com dificuldades, 13 vinham de famílias com renda mensal inferior a 10 salários mínimos, numa proporção de $76 \%$, enquanto no conjunto da quarta série essa proporção era de $39 \%$. Com isso fecha-se o círculo, caracterizando o grupo de alunos com problemas frente à escola como mais pobre, mais masculino $e$ mais negro que o conjunto das crianças das quartas séries de 2000.

O que estou propondo é que consideremos o processo complexo de atribuição de cor e de raça no contexto escolar como um processo com múltiplas direções: ao mesmo tempo a raça negra seria mais facilmente atribuída a crianças com dificuldades escolares, mas também esses problemas escolares, tanto de aprendizagem quanto de disciplina, podem estar se desenvolvendo com maior freqüência entre crianças percebidas e que se auto-percebem como negras. Frente ao racismo $e$ ao silêncio quanto às relações inter-raciais $e$ às particularidades da 
Articulações entre gênero e cor/raça

produção cultural da população negra, já constatados em nossas escolas por diversos estudos ${ }^{40}$, essas crianças tenderiam a desenvolver uma relação difícil, dolorosa mesmo, tanto com a escola como instituição, quanto com a aprendizagem propriamente dita, encontrando muito mais obstáculos para atingir o sucesso escolar que as crianças percebidas como brancas.

Embora não tenhamos presenciado cenas de discriminação aberta por parte das professoras nessa escola em particular, sabemos que o silêncio, a ausência de modelos e a negação através dos currículos e materiais didáticos são formas veladas de racismo, que podem estar tornando a escola, enquanto instituição, hostil às crianças negras.

Internalizando o pertencimento racial a elas atribuído, já que se trata de um processo de construção de identidades e não de uma característica fixa ou essencial, seriam as crianças com identidades negras consistentemente estabelecidas (coerência entre a hetero $e$ a auto-atribuição) mais freqüentemente encontradas no grupo das crianças com dificuldades escolares, uma vez que essa identidade vem carregada de significados negativos. As meninas, desenvolvendo em menor proporção comportamentos abertamente indisciplinados ou transgressores, seriam também ao mesmo tempo menos percebidas como negras e como portadoras de dificuldades escolares.

Um conjunto de estudos anglo-saxões sobre a construção de identidades masculinas em escolas vem indicando como diferentes masculinidades são construídas em relação à diferenciação hierarquizada em que a escola aloca os estudantes, através da constante competição e classificação. À medida que se reconhecem como fracassados na escola, vendo fechar-se as

${ }^{40}$ CAVAlleiro, Eliane. Do silêncio do lar ao silêncio escolar: racismo, preconceito e discriminação na educação infantil. São Paulo, Contexto, 2000; GONÇALVES, Luis Alberto. O silêncio: um ritual pedagógico a favor da discriminação. Dissertação de Mestrado, Belo Horizonte, FFMG, 1985; e Reflexão sobre a particularidade cultural na educação das crianças negras. Cadernos de Pesquisa, n 63, São Paulo, novembro de 1987, pp.27-30, entre outros. 
Marília Pinto de Carvalho

possibilidades de realizar um certo padrão de masculinidade e de controlar um certo tipo de poder social ligados ao sucesso acadêmico, alguns jovens, principalmente oriundos de famílias de baixa renda, podem reagir buscando outras fontes de poder, até mesmo outras definições de masculinidade, muitas vezes simbolizadas numa postura anti-escolar, na valorização de habilidades esportivas e da força física, e também na agressividade e em conquistas heterossexuais. ${ }^{41}$

A pesquisadora inglesa Christine Skelton, relatando estudo etnográfico sobre a construção de identidades masculinas que realizou em duas escolas primárias de Londres, procura avaliar em que medida essas conclusões - extraídas de estudos na maioria referentes a jovens alunos de escolas secundárias - podem ser aplicadas a crianças. Para Skelton, enquanto o ensino primário inglês foi baseado em pedagogias centradas no aluno $e$ voltadas para o desenvolvimento integral dos indivíduos, as classificações escolares eram pouco relevantes na definição da postura dos meninos frente à escola e na diferenciação entre formas de masculinidade. Contudo, a introdução de testes padronizados e a ênfase na avaliação dos alunos e das escolas, nos anos 90 , teria re-introduzido "a instrumentalização do fracasso acadêmico através da classificação e hierarquização competitivas" ${ }^{2}$, o que também trouxe à tona a questão de que são meninos a maioria dos "fracassados". Considerando o caráter historicamente excludente e classificatório de nossa escola primária ${ }^{43}$, é possível

${ }^{41}$ CONNELL, Robert W. Disruptions: improper masculinities and schooling. In: Kimmel, M. e Messner, M. (eds.) Men's lives. Boston, Allyn and Bacon, 1998; CONNOLLy, Paul. Racism, gender identities and young children: social relations in a multi-ethnic. Inner-city primary school. London, Routledge, 1998; MAC AN GHAILl, M. The Making of Men... Op. cit.; SEWELl, Tony. Black masculinities and schooling: how black boys survive modern schooling. London, Trentham, 1997 e Loose canons: exploding the myth of the black macho lad. In: EPSTEIN, Debbie et alli. (eds.) Failing Boys?... Op. cit.

${ }^{42}$ SKELTON, Christine. Schooling the boys: masculinities and primary education. Buckingham, Open University Press, 2001, p.26.

${ }^{43}$ PAtTo, M. H. S. A produção do fracasso escolar... Op. cit. 
Articulações entre gênero e cor/raça

supor que a hipótese de diferentes masculinidades articuladas à hierarquização escolar faça sentido para nossos meninos.

Da mesma forma, grupos culturais e étnicos de jovens também teriam um papel significativo nesse processo, ao valorizar formas de afirmação baseadas, entre outros valores, na capacidade de transgredir e enfrentar as regras escolares. Estudando jovens negros de origem caribenha, em uma escola pública inglesa, Tony Sewell encontrou diversos tipos de masculinidade e de posturas frente à escola. Dentre elas, localiza um grupo de garotos "rebeldes", que "substituíam os objetivos e métodos da escola por sua própria agenda. Eram freqüentemente punidos e sentiam-se confortáveis num machismo negro anti-escolar", do qual fazia parte o orgulho pela reputação cuidadosamente cultivada de ser "mau aluno". ${ }^{44}$ Nesse grupo, os meninos brancos eram vistos como efeminados e com baixo desempenho em termos daqueles valores ligados à agressividade, à força física, ao enfrentamento das regras e a conquistas heterossexuais. Esses alunos tinham consciência de ser até mesmo admirados por garotos brancos, tanto por sua atitude anti-escola quanto pelo grau de masculinidade que isso representava.

Sewell também chama a atenção para a postura dos professores e professoras frente aos rapazes negros de origem caribenha, tratando-os não como indivíduos com características particulares, mas de forma estereotipada, pressupondo sua agressividade e mau comportamento. Isso, ao lado da pressão dos colegas, dificultava a adesão aos valores e exigências escolares, mesmo para aqueles meninos que buscavam posturas conformistas e afastavam-se dos grupos de colegas afrocaribenhos.

Apesar desses garotos afirmarem partilhar o ethos dominante da escola, no qual as turmas de rapazes negros eram percebidas como negativas, muitos eram ainda assim vistos como parte de uma "questão afro-caribenha" mais ampla. Eles não

${ }^{44}$ SEWELL, T. Loose canons... Op. cit., p.120 
Marília Pinto de Carvalho

podiam nunca escapar efetivamente da marca de suas peles $e$ gênero. ${ }^{45}$

Alguns de nossos alunos da quarta série talvez estivessem dando os passos iniciais numa trajetória daquele tipo, de busca de outras fontes de poder e mesmo outras formas de masculinidade. Não apenas eles possivelmente traziam de casa e desenvolviam no grupo de colegas referenciais de masculinidade diferentes dos valorizados pelas professoras, um padrão mais assentado no desempenho físico, na agressividade e na heterossexualidade, com diferenças de gênero mais acentuadas. Além disso, a própria escola, ao empurrá-los para o fracasso acadêmico, ao identificá-los com um padrão negativo de "garoto negro", poderia estar contribuindo para que eles assumissem essas formas de masculinidade como única via para controlar algum poder e autonomia, elementos indispensáveis na confirmação de identidades masculinas, já que a masculinidade está organizada, em escala macro, em torno do exercício de poder. Eles estariam "lidando com as múltiplas incertezas de sua posição desenvolvendo o que era considerado pelos adultos da escola como agressividade, abuso de poder e mesmo violência". ${ }^{46}$

Ao deixar intocada a discussão sobre as desigualdades raciais e sobre a relação intrínseca e pretensamente natural entre masculinidade e poder, enquanto ao mesmo tempo dificulta o acesso a formas de poder socialmente aceitáveis, como através do reconhecimento acadêmico, a escola pode estar contribuindo na construção de trajetórias que venham a desembocar em violência. Os problemas crescentes de indisciplina, agressividade física e verbal, formação de gangue e pequenos furtos, que a escola estudada registrava em relação a uma parte desses meninos em 2001, quando já eram alunos da $5^{\mathrm{a}}$ série, parecem apontar nessa direção.

${ }^{45}$ SeWELL, T. Loose canons... Op. cit., p.115.

${ }^{46}$ ARNOT, Madeleine et alli. Closing the gender gap: postwar education and social change. Cambridge, Polity Press, 1999, p.144. 
Articulações entre gênero e cor/raça

\section{As crianças orientais}

Como vimos, as professoras não tiveram dúvidas para classificar as mesmas cinco crianças (um menino e quatro meninas) como orientais, comentando que os próprios sobrenomes já eram um indicador, todos eles aparentemente de origem japonesa. $\mathrm{O}$ mesmo, contudo, não se pode dizer dessas crianças. Apenas três delas assinalaram a opção "oriental" na questão dirigida, uma menina assinalou "pardo" e um menino assinalou "branco". A confusão entre cor, raça e ascendência (etnia?) é visível nas respostas dadas à questão aberta. A menina que assinalou a opção "pardo", explicou na questão livre que sua cor era "parda, mas a raça, oriental"; já o menino que se atribuiu a cor branca, respondeu: "Meus bisavô (sic) é japonês mas eu não sou amarelo". Outras respostas de meninas foram: "A minha cor é branca e raça japonesa"; "sou neta de japonesa"; "oriental (japonesa)".

As respostas das crianças, na verdade, refletem um embaralhamento conceitual que está presente tanto na questão formulada pelo IBGE e nas alternativas ali oferecidas ("A sua cor ou raça é: 1-branca; 2-preta; 3-amarela; 4-parda; 5-indígena"), quanto na questão que lhes apresentamos, em que a alternativa "oriental" substituiu "amarela"; e expressam a complexidade de elementos que se combinam na classificação racial no contexto brasileiro, já discutida em outros estudos. ${ }^{47}$ Acreditamos que nosso engano ao substituir o termo "amarelo" por "oriental" também está relacionado a esse embaralhamento, além dos sentidos pejorativos associados à classificação "amarelo". É interessante notar que, mesmo sem que a palavra tivesse sido mencionada, ela apareceu numa das respostas. Até que ponto a cor efetivamente serve como metáfora para a raça (socialmente determinada)? Em que momento elas se tornam disjuntivas? No caso de

${ }^{47}$ PizA, E. e Rosemberg, F. Cor nos censos brasileiros. Op. cit.; Telles, E. Racismo à brasileira... Op. cit. 
Marília Pinto de Carvalho

ascendências com traços fenotípicos marcados, como as orientais, será a origem o mais forte marcador racial no Brasil?

Uma mensagem eletrônica a nós enviada por uma funcionária do IBGE, em resposta a questões que lhes fizemos sobre a forma de indagação utilizada no Censo, é extremamente esclarecedora dessa mistura de critérios. Além de reproduzir o formulário utilizado pelo IBGE, a Sra. Maria Tereza Reis teve a gentileza de nos enviar algumas instruções que são passadas aos recenseadores. Nelas podemos ler:

considere que amarela só se aplica à pessoa de origem japonesa, chinesa, coreana etc. Não considere, como amarela, a pessoa que tenha a pele amarelada por sofrer de moléstia como impaludismo, malária, amarelão etc.

Além de entrar em conflito com outra orientação apresentada logo a seguir nesse mesmo texto, que afirma a necessidade da auto-atribuição de cor pelo entrevistado, o comentário sobre a opção "amarelo" é muito revelador das ambigüidades da classificação por cor que apontamos acima, em suas misturas com critérios de origem, ascendência e etnia.

Considerado o conjunto de nosso formulário (questão livre e questão dirigida), nenhuma das cinco crianças classificadas como orientais pelas professoras negou sua ascendência, mas os textos livres $e$ as discrepâncias entre as respostas denotam dificuldade $e$ incômodo para se incluírem nas categorias disponíveis, ainda que não tivéssemos usado a palavra "amarelo". Por isso, embora em diversas passagens dessa análise elas estejam incluídas na categoria "não negros", pareceu-me necessário destacá-las e refletir um pouco sobre suas características. ${ }^{48}$

${ }^{48}$ As duas crianças que se auto-classificaram como indígenas, também incluídas no grupo de "não-negros", não foram estudadas em maior detalhe pois o centro dessa análise são as posturas e classificações das professoras e, para estas, a menina era branca e o menino pardo. Na avaliação de Célia e Laís, as crianças tinham apenas brincado ao se classificarem como indígenas. 
Articulações entre gênero e cor/raça

Elas compõem pouco mais de $8 \%$ do total de alunos da $4^{\mathrm{a}}$ série (5 em 60 ). Quatro provêm de famílias com renda superior a 10 salários mínimos mensais e a única exceção é uma menina cujos pais, apesar de declararem renda média familiar mais baixa, têm, ambos, escolaridade de nível superior completo. Na visão das professoras, parecem ser um grupo quase invisível: não constam nos registros de punições escolares e nenhum deles foi indicado para reforço; três das meninas não foram mencionadas nas falas das professoras, a quarta foi indicada como boa aluna, mas "aquela que não pisca na aula... não questiona, nada, nada." (Célia); e o único menino foi citado como bom aluno, sem nenhum outro comentário. Portanto, pareceu-me que são crianças que "não dão trabalho", por isso tendem a desaparecer no roldão das solicitações e problemas cotidianos da sala de aula. Como seu pertencimento racial não é gerador de desigualdades marcantes como no caso dos negros, ele também acaba por ser silenciado $e$ muitas vezes se pressupõe que não é fonte de dificuldades. As respostas ao questionário, contudo, indicam no mínimo um desconforto, que merece uma discussão específica.

Estudos norte-americanos indicam uma situação semelhante, tanto no que se refere às características estereotipadas atribuídas aos alunos de origem asiática, como serem estudiosos, colaborativos e dóceis, mas pouco comunicativos e mais afeitos às disciplinas científicas e exatas; quanto do ponto de vista dos próprios estudantes, que se mostram pouco à vontade frente a sua identidade étnica. ${ }^{49}$ No Brasil, Luiza M. Y. Camacho ${ }^{50}$ investigou

${ }^{49}$ CHUN, Ki-Taek. The myth of Asian American success and its educational ramifications. In: NAKANISHI, D. \& NISHIDA, T. Y. The Asian American educational experience: a source book for teachers and students. New York, Routledge, 1983, pp.95-111; SUE, Stanley \& OKASAKI, Sumie. Asian American educational achievements: a phenomenon in search of an explanation. American Psychologist, $\mathrm{n}^{\circ}$ 45, 1990, pp.913-920.

${ }^{50}$ CAMACHO, Luiza Mitiko Yshiguro. As relações entre a culturas japonesa e a educação dos nipo-brasileiros: um estudo dos elementos influenciadores do desempenho escolar dos descendentes de japoneses. Dissertação de Mestrado, PUC-SP, Programa de História e Filosofia da Educação, 1993. 
Marília Pinto de Carvalho

as razões que levariam estudantes nipo-brasileiros a um bom desempenho escolar. Através de entrevistas com famílias residentes em São Paulo, a autora concluiu que a forte presença de valores da cultura tradicional japonesa, como a hierarquia, a vergonha, a auto-disciplina $e$ a responsabilidade, ao lado de intensa valorização da educação escolar, estariam na base de um comportamento de compromisso e empenho no processo de escolarização. Seus depoentes também relatam a presença de estereótipos e de um marcante sentimento de superioridade frente aos "gaijin" (brasileiros).

De toda forma, parece clara a necessidade de uma investigação mais aprofundada do tema, capaz de dar voz também às crianças descendentes de orientais.

\section{$\mathrm{O}$ que as crianças escreveram}

Cinco alunos (dois meninos e três meninas) interferiram nas opções oferecidas na questão dirigida: um menino marcou todas as opções $e$ as outras quatro crianças criaram categorias ligadas à raça negra: mestiço, negro ou moreno, duas delas anulando a opção "preto" e outras duas a opção "pardo". Na pergunta aberta, escreveram as mesmas palavras, deixando muito evidente seu desconforto com a terminologia utilizada e sua dificuldade em identificar-se com categorias como preto e pardo. Destaque-se que nenhuma criança que assinalou a opção "branco" interferiu no questionário.

$\mathrm{Na}$ questão livre, o resultado foi bastante parecido com o encontrado na PNAD de 1976, que apresentou uma questão aberta sobre a cor da população. Naquele momento, apesar da grande variedade de respostas, predominou a categoria "moreno" entre aqueles que se classificaram como "pardos" no quesito fechado. ${ }^{51}$ Entre nossas crianças, dez lançaram mão desse termo, às vezes acompanhado de especificações como "moreno-negro", "moreno

${ }^{51}$ ARAújo, T. C N. A classificação de "cor" nas pesquisas do IBGE... Op. cit. 
escuro", "moreno claro" ou "meio moreno, meio branco". Outra cor mencionada foi "marrom claro". A essas respostas livres corresponderam, na questão dirigida, cinco opções para pardo, três para preto, uma para branco e uma para indígena. Mais uma vez, a dificuldade em definir a cor de uma pessoa e toda a carga negativa associada às categorias preto e pardo, parecem ter sido decisivas nas respostas. A força da categoria branco como referência, como universal, quase como resposta correta entre as opções, aparece na seguinte resposta livre: "Eu me acho pardo, porque minha pele não é tão branca". Deixando no ar a pergunta: não é tão branca quanto deveria? Apenas duas meninas deram respostas livres que pareciam afirmar com algum orgulho a raça negra: "Sou negra de família negra" e "A minha raça é de origem negra". Duas outras acrescentaram à sua cor branca, uma característica valorizada, da qual pareciam orgulhar-se: "loira". Resistências, movimentos, hierarquias e desigualdades pulsam nas respostas das crianças.

Como a primeira questão abria a possibilidade para uma resposta relativa à raça ("Qual a sua cor ou raça?"), alguns alunos $e$ alunas deram respostas duplas, do tipo: "cor preta, raça não sei". Além dos orientais, um menino e uma menina brancos mencionaram sua ascendência ("sou branco e milanês"; "descendente de libanês"). Além disso, dois meninos e três meninas apresentaram-se como "brasileiros", quatro deles classificando-se como brancos. Já que nenhuma criança que se classificou como preta ou oriental fez o mesmo tipo de afirmação (e apenas uma parda ${ }^{52}$ ), fica sugerida uma associação entre cor branca e brasilidade, que esses alunos certamente reproduziram a partir de uma imagem muito difundida no país (um bom exemplo são os livros didáticos), de uma nação de cara branca, imagem que sem dúvida precisa ser discutida frente ao fato de que $45 \%$ de nossa população se declara preta ou parda.

${ }^{52}$ Um segundo menino auto-classificado como pardo escreveu: "Eu sou paulista". 
Todavia, a mensagem mais contundente partiu de um menino negro (hetero-atribuição pelas professoras $e$ pesquisadora), um dos "meninos problema" da turma, freqüentador do reforço $e$ assíduo nas páginas do livro de advertências da escola. Além de assinalar todas as opções na questão fechada, ele escreveu: "branco = pardo = preto". Em entrevista posterior, esse aluno confirmou sua opinião afirmando que respondera assim porque "é tudo igual mesmo". Sua resposta inesperada, pois ele em geral se mostrava calado e indiferente, expressa à sua maneira, num código simples e direto, como se estivesse grafitando uma parede, a revolta contra essas classificações e as desigualdades a elas ligadas, ao mesmo tempo que apresenta sua utopia - nossa utopia - de um mundo de iguais, de seres humanos que se equivalem para além da cor da pele: "branco = pardo = preto". 
Articulações entre gênero e cor/raça

Tabela 1

Auto-classificação por cor segundo o sexo da criança

\begin{tabular}{|l|c|c|c|c|c|c|c|c|}
\cline { 2 - 9 } \multicolumn{1}{c|}{} & Branco & Pardo & Preto & Oriental & Indígena & $\begin{array}{c}\text { Não } \\
\text { fez }\end{array}$ & Outro & Total \\
\hline Masculino & 7 & 10 & 5 & 0 & 1 & 1 & 1 & 25 \\
\hline Feminino & 19 & 7 & 5 & 3 & 1 & 0 & 0 & 35 \\
\hline Total & 26 & 17 & 10 & 3 & 2 & 1 & 1 & 60 \\
\hline
\end{tabular}

Tabela 2

Diferentes classificações por raça

\begin{tabular}{|l|c|c|c|}
\hline & Não-negro & Negro & Não resp. \\
\hline Célia & 44 & 16 & 0 \\
\hline Laís & 37 & 23 & 0 \\
\hline Auto & 31 & 27 & 2 \\
\hline
\end{tabular}


Marília Pinto de Carvalho

Tabela 3

Hetero-classificação por raça

segundo participação no reforço e punições disciplinares

\begin{tabular}{|l|c|c|c|c|c|c|c|}
\cline { 2 - 8 } \multicolumn{1}{c|}{} & Total & Reforço & & Punições & & $\mathrm{R}+\mathrm{P}^{*}$ & \\
\cline { 3 - 8 } \multicolumn{1}{c|}{} & & $\mathrm{n}^{\circ}$ & $\%$ & $\mathrm{n}^{\circ}$ & $\%$ & $\mathrm{n}^{\circ}$ & $\%$ \\
\hline Não negros & 34 & 6 & 17 & 1 & 3 & 6 & 17,5 \\
\hline Negros & 17 & 7 & 41 & 6 & 35 & 10 & 59 \\
\hline Discrepantes & 9 & 0 & 0 & 0 & 0 & 0 & 0 \\
\hline Total & 60 & 13 & 21 & 7 & 11 & 16 & 26,5 \\
\hline
\end{tabular}

Tabela 4

Auto-classificação por raça segundo participação no reforço e punições disciplinares

\begin{tabular}{|l|c|c|c|c|c|c|c|}
\cline { 2 - 8 } \multicolumn{1}{c|}{} & Total & Reforço & & Punições & & $\mathrm{R}+\mathrm{P}^{*}$ & \\
\cline { 2 - 8 } \multicolumn{1}{l|}{} & $\mathrm{n}^{\circ}$ & $\%$ & $\mathrm{n}^{\circ}$ & $\%$ & $\mathrm{n}^{\circ}$ & $\%$ \\
\hline $\begin{array}{l}\text { Não } \\
\text { negros }\end{array}$ & 31 & 5 & 16 & 1 & 3 & 5 & 16 \\
\hline Negros & 27 & 6 & 22 & 4 & 14 & 9 & 33 \\
\hline $\begin{array}{l}\text { Não } \\
\text { respondeu }\end{array}$ & 2 & 2 & 100 & 2 & 100 & 2 & 100 \\
\hline Total & 60 & 13 & 21 & 7 & 11 & 16 & 27 \\
\hline
\end{tabular}

*Quatro crianças estão no reforço e também sofreram punições 
Articulações entre gênero e cor/raça

Gráfico 1

Defasagem idade-série média na faixa etária de 10 a 18 anos, sequndo sexo e cor. Brasil, 1999

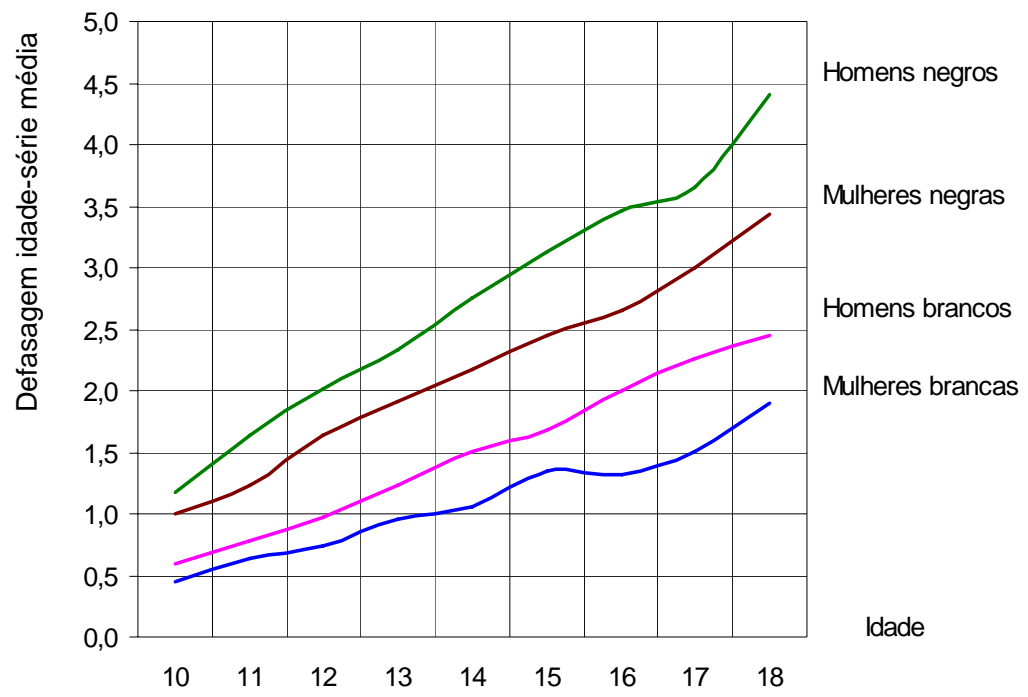

Fonte: PNAD 1999 apud Rosemberg, 2001. 